\title{
Evaluation of antioxidant potential of Brazilian rice cultivars
}

\section{Sylvio Vicentin PALOMBINI ${ }^{1}$, Swami Arêa MARUYAMA ${ }^{1}$, Thiago CLAUS ${ }^{1}$, Fabiana CARBONERA ${ }^{1}$, Nilson Evelázio de SOUZA², Jesuí Vergílio VISENTAINER ${ }^{1}$, Sandra Teresinha Marques GOMES ${ }^{1}$, Makoto MATSUSHITA ${ }^{1 *}$}

\begin{abstract}
This study quantified the fatty acids and evaluated the proximate composition, antioxidant activity (using the Quencher procedure), and total phenolic compound concentrations in Brazilian rice cultivars. The cultivars studied showed high amounts of unsaturated fatty acids, such as linoleic and oleic acid. The ratios of polyunsaturated and saturated fatty acids obtained were high. Regarding the antioxidant activity, the best results were found using the ABTS method and the worst in the DPPH assay. The results of the DPPH and FRAP assays showed the highest correlation. The antioxidant capacity results obtained were also much higher than those reported for other varieties worldwide. Therefore, the Quencher procedure is highly suitable for application in cereals such as rice, especially when combined with the ABTS radical capture method.
\end{abstract}

Keywords: Brazilian rice; antioxidant assays; Quencher procedure.

\section{Introduction}

Rice (Oryza sativa L.) is a staple food in many countries, especially in developing countries. It is an important crop in Africa, Latin America, and the Middle East, representing the second largest crop produced worldwide (FOOD..., 2013; SELLAPAN et al., 2009). It is an important source of vitamins, minerals, fibers, and other bioactive compounds (MONKS et al., 2013). Brazil is among the ten greatest producers of this grain, with an annual production of more than 13 million tons (FOOD..., 2013).

Many studies in the literature report the antioxidant activity of different rice genotypes (QIU; LIU; BETA, 2010; SOMPONG et al., 2011; ZIGONEANU et al., 2008). In general, an antioxidant compound is any substance that when present at low concentrations compared to that of an oxidizable substrate, effectively delays or inhibits its oxidation (SIES; STAHL, 1995). Nowadays, there is great concern about the damage caused by oxidative stress, which can harm DNA inducing carcinogenic effects (KLAUNIG et al., 2011). As a result, the importance of studying the antioxidant capacity of foods has increased.

Currently, there are many analytical methods to determine the antioxidant capacity in different food matrices (BENZIE; STRAIN, 1996; BRAND-WILLIAMS; CUVELIER; BERSET, 1995; CAO; ALESSIO; CUTLER, 1993; RE et al., 1999). These assays make use of analyte extraction steps with solvents for later analysis. They often substantially increase total procedure time and require toxic solvents, which do not extract all of the compounds that can be detected by total antioxidant activity (TAA) determination techniques. Therefore, it leads to an underestimation of the final results (GÖKMEN; SERPEN; FOGLIANO, 2009) since molecules with antioxidant capacity can also act in synergy with themselves (LEVINE et al., 1996).
However, there is a procedure, called Quencher, which overcomes this problem. It is directly applied to the food matrix, avoiding solvent extraction and sample hydrolysis steps. The radical compounds that are used in the assays, combined by this direct procedure, come into contact with both the soluble and insoluble parts of foods, hence increasing the accuracy of the TAA measurement. Moreover, the results generated by this procedure are more realistic since they take into consideration the effects that occur between the antioxidant compounds in a food matrix (synergism, for example), while in multiple extraction procedures, the total antioxidant capacity is only represented by the sum of the antioxidant capacities of the soluble and insoluble fractions measured at different times (GÖKMEN; SERPEN; FOGLIANO, 2009).

The Quencher procedure has been previously employed in different food matrices, such as cereals, beef and walnuts (AÇAR; GÖKMEN; PELLEGRINI, 2009; SERPEN; GÖKMEN; FOGLIANO, 2012a; SERPEN et al., 2008). However, no author has ever used this procedure in Brazilian rice cultivars. Thus, this study aimed to determine the TAA of different Brazilian rice cultivars using DPPH and ABTS radical capture assays and the ferric reduction antioxidant power (FRAP) method, all combined with the Quencher procedure. Furthermore, the proximate composition and the total amount of phenolic compounds present in the studied cultivars were also determined, and their fatty acids were quantified.

\section{Experimental}

\subsection{Grain sampling}

All the rice cultivars (BRS Primavera, BRS Querência, BRS Sertaneja, BRS Tropical, BRS Taim, BRS Jaçanã, and BRS Pampa)

\footnotetext{
Received 4/30/2013

Accepted 9/11/2013 (006081)

1 Department of Chemistry, State University of Maringá - UEM, Av. Colombo, 5790, CEP 87020-900, Maringá, PR, Brazil, e-mail: mmakoto@uem.br

${ }^{2}$ Food Technology Department, Federal University of Technology - Paraná State - UTFPR, Londrina, PR, Brazil

${ }^{*}$ Corresponding author
} 
were harvested from the experimental area of the Capivara farm (Latitude: $16^{\circ} 28^{\prime} 00^{\prime \prime}$ Longitude: $49^{\circ} 17^{\prime} 00^{\prime \prime}$ Altitude: 823.00 meters) of the EMBRAPA Arroz e Feijão unit in 2012 and stored until analysis. All samples were ground separately.

\subsection{Chemical analysis}

All analyses were performed in three replicates. Total lipids (TL) of the rice samples were determined according to the method of Bligh and Dyer (1959). Moisture content was determined using the AOAC Official Method 930.15, ash content using the AOAC Official Method 942.05, and crude protein (CP) following the AOAC Official Method 960.52 (ASSOCIATION..., 1990), using a factor of 6.25 to convert the percentage of nitrogen into protein percentage. The Nifext fraction was estimated by difference.

\subsection{Fatty acid composition}

Fatty acid methyl esters (FAME) were prepared by total lipid methylation following the method of Hartman and Lago (1973). The methyl esters were separated by gas chromatography in a Varian 3380 (USA) gas chromatography fitted with a flame ionization detector (FID) and a fused-silica capillary column $(100 \mathrm{~m} \times 0.25 \mathrm{~mm}$ id., $0.25 \mu \mathrm{m}$ cyanopropyl CP-7420 select FAME). The injector and detector temperatures were 200 and $240{ }^{\circ} \mathrm{C}$, respectively. The column temperature was maintained at $185^{\circ} \mathrm{C}$ for 8 minutes, followed by a heating rate of $4{ }^{\circ} \mathrm{C} \mathrm{min}{ }^{-1}$ up to $235^{\circ} \mathrm{C}$, which was maintained for 0.5 minute. The ultrapure gas flows were $1.2 \mathrm{~mL} \mathrm{~min}^{-1}$ for the carrier gas (hydrogen), $30 \mathrm{~mL} \mathrm{~min}^{-1}$ for the make-up gas (nitrogen), $350 \mathrm{~mL} \mathrm{~min}^{-1}$ for the synthetic air, and $35 \mathrm{~mL} \mathrm{~min}{ }^{-1}$ for the hydrogen flame gas, with a split injection ratio of $1 / 80$.

For the identification of fatty acids, the retention times were compared to those of standard methyl esters (Sigma, USA). Quantification of fatty acids was performed using tricosanoic acid methyl ester (Sigma, USA) as an internal standard, according to Joseph and Ackman (1992). Peak areas were determined using the software Star 5.0 (Varian, USA).

\subsection{Antioxidant capacity analysis}

For the antioxidant capacity analysis, all previously ground samples were passed through an 80 mesh $(0.177 \mathrm{~mm})$ sieve to avoid any influence of different particle sizes on the Quencher procedures (GÖKMEN; SERPEN; FOGLIANO, 2009).

The work solutions used in this study were prepared according to Serpen, Gökmen and Fogliano (2012a). The stock solution of 2,2-diphenyl-1-picrylhydrazyl (DPPH) used was obtained by dissolving $40 \mathrm{mg}$ of DPPH in $200 \mathrm{~mL}$ of ethanol/ water mixture (50:50, v/v). The absorbance value of $0.75-0.80$ was set by diluting the stock solution in approximately $800 \mathrm{~mL}$ of a water/ethanol (50:50, v/v) mixture.

For the ABTS assay, the stock solution of ABTS•+ (2,2'-azinobis-(3-ethylbenzothiazoline-6-sulfonic acid)) was prepared according to Re et al. (1999), by reacting the ABTS stock solution $\left(7 \mathrm{~mol} \mathrm{~L}^{-1}\right)$ with potassium persulfate $(2.45 \mathrm{~mol}$ $\left.\mathrm{L}^{-1}\right)$. The final solution was allowed to stand in the dark at room temperature for 12-16 hours before use. The working solution of $\mathrm{ABTS}^{*+}$ was prepared by diluting $10 \mathrm{~mL}$ of stock solution with $800 \mathrm{~mL}$ of a water/ethanol (50:50, v/v) mixture to obtain an absorbance of 0.75-0.80 at $734 \mathrm{~nm}$ (SERPEN; GÖKMEN; FOGLIANO, 2012a).

The FRAP solution was prepared as described by Benzie and Strain (1996), diluting an aqueous solution of $10 \mathrm{mmol}$ $\mathrm{L}^{-1}$ TPTZ (2,4,6-tripyridyl-s-triazine) and $20 \mathrm{mmol} \mathrm{L}^{-1}$ ferric chloride in $300 \mathrm{mmol} \mathrm{L}^{-1}$ sodium acetate buffer $(\mathrm{pH} 3.6)$ at the ratio of 1:1:10 $(\mathrm{v} / \mathrm{v} / \mathrm{v})$.

Ten milligrams of each previous ground sample was weighed in a centrifuge tube. For the DPPH, $\mathrm{ABTS}^{\cdot+}$, and FRAP assays, $10 \mathrm{~mL}$ of the respective working solutions were added to start the reactions. All tubes were shaken for 1 hour and centrifuged at $9200 \mathrm{~g}$ for 5 minutes. The absorbance of the supernatants was measured at $734 \mathrm{~nm}$ (for ABTS assay), 525 $\mathrm{nm}$ (for DPPH assay) and $593 \mathrm{~nm}$ (for FRAP assay) (SERPEN; GÖKMEN; FOGLIANO, 2012a).

Trolox (6-hydroxy-2,5,7,8-tetramethychroman-2carboxylic acid) was used as a standard reference to convert the inhibition capability of each sample into the trolox equivalent antioxidant capacity (TEAC), as described by Serpen, Gökmen and Fogliano (2012a).

The extraction of the antioxidant compounds needed for the total phenolic assay was carried out using $10 \mathrm{~g}$ of each ground grain and $100 \mathrm{~mL}$ of a mixture of ethanol and water $(50: 50, \mathrm{v} / \mathrm{v})$, stirring for 4 hours with a magnetic bar (SANTOS et al., 2011).

The total phenolic content was determined according to the method of Shahidi and Naczk (1995). A $0.25 \mathrm{~mL}$ aliquot of the extract solution was mixed with $0.25 \mathrm{~mL}$ of Folin-Ciocalteu's reagent previously diluted with water $(1: 1, \mathrm{v} / \mathrm{v}), 0.5 \mathrm{~mL}$ of a saturated sodium carbonate solution, and $4 \mathrm{~mL}$ of water. The mixture was allowed to rest at room temperature for 25 minutes and was then centrifuged at $3800 \mathrm{~g}$ for 10 minutes. The supernatant absorbance was measured at $725 \mathrm{~nm}$ using a spectrophotometer (Cary Win UV 50, Varian). Gallic acid (GA) was used as the standard, and the results were expressed as gallic acid equivalents $\left(\mathrm{mg} \mathrm{GAE} 100 \mathrm{~g}^{-1}\right)$.

\subsection{Statistical analysis}

The results were submitted to analysis of variance (ANOVA), and the means were compared by the Tukey's test using the Statistica program, version 7.0. The significance level used for rejection of the null hypothesis was $5 \%(\mathrm{p}<0.05)$. The correlation coefficients (R) used to determine the relationship between the antioxidant activity measured and total phenolic content were calculated using Microsoft Office Excel software, version 2010.

\section{Results and discussion}

Table 1 shows the results of the proximate composition analyses for the rice cultivars. Total lipid contents ranged between 1.77-3.12\%, higher than the value found by Oduguwa, Edema and Ayeni (2008) (1.42\%) and 11 times greater than that obtained by Padovani et al. (2007) ( $0.27 \%)$, both for white rice. 
As for the crude protein contents, the values that were obtained for Brazilian rice cultivars were similar to that (approximately) reported by Sompong et al. (2011) (9\%) for red and black species of rice and slightly higher than the range found by Juliano (2004) (7.1-8.3\%) for different rice types. The average value of ash content of the studied samples (1.15\%) was within the 1.0-1.5 $\%$ range, determined by this same author (JULIANO, 2004). These results show that the cultivars that have been adapted for farming and consumption in Brazil are good lipid and crude protein sources compared to other rice varieties (black and red, for example).

In terms of lipid profile (Table 2), BRS Primavera and BRS Jaçanã cultivars stand out from the others. BRS Primavera had the lowest value of total saturated fatty acids (SFA) and the highest value of total polyunsaturated fatty acids (PUFA), leading to the highest PUFA/SFA ratio among the cultivars. The values of this ratio were above the minimum required $(0.45)$ for a foodstuff to be considered healthy for all samples (LONDON, 1994). The cultivar BRS Jaçanã showed the highest concentration of $a$-linolenic acid and the lowest n-6/n-3 ratio.

All cultivars showed high amounts of oleic acid (39.86\%) and lower values of total SFA (20.71\%) when compared to the values obtained by Monks et al. (2013) (38.5\% and 24.4\% for 18:1n-9 and SFA, respectively) and Kitta et al. (2005) (36.9\% and $24.3 \%$ for $18: 1 n-9$ and AGS, respectively) in different rice cultivars. The intake of $18: 1 n-9$ instead of saturated fatty acids helps reduce the low density lipoprotein levels in the blood and therefore reduces the risk of cardiovascular disease (ELMADFA; KORNSTEINER, 2009). As for the $\alpha$-linolenic acid levels, The Brazilian cultivars showed an amount ranging from 1.24-2.57\%, higher than the values found by Kitta et al. (2005) (1.2\%, mean). According to Perini et al. (2010), $\alpha$-linolenic acid is an essential fatty acid that is not synthetized by humans and must be provided by an adequate diet.

Regarding the antioxidant activity and the total content of phenolic compounds (Table 3), all cultivars, except for BRS Taim and BRS Jaçanã, showed the highest in the ABTS assay, followed by FRAP and DPPH. BRS Taim showed the best results and the highest concentrations of total phenolic compounds (TPC) in all assays.

In the DPPH assay, the values ranged from 794.51 to $1461.66 \mu \mathrm{mol} \mathrm{TEAC} \mathrm{g}^{-1}$. This range was much higher than that determined by Qiu, Liu and Beta (2010) (159 to $540 \mu \mathrm{mol}$ TEAC $100 \mathrm{~g}^{-1}$ ) for different rice types. As for the ABTS assay, the cultivars showed an average value $\left(164 \mathrm{mmol}^{100 \mathrm{~g}^{-1}}\right)$ higher than those reported for other species, such as black and red rice

Table 1. Proximal composition of rice cultivars (\%).

\begin{tabular}{cccccc}
\hline & Moisture & Ash & Crude protein & Total lipids \\
\hline BRS Primavera & $11.88 \pm 0.03^{\mathrm{c}, \mathrm{d}}$ & $1.03 \pm 0.07^{\mathrm{c}}$ & $11.65 \pm 0.49^{\mathrm{a}}$ & $3.12 \pm 0.13^{\mathrm{a}}$ & $72.25 \pm 0.50^{\mathrm{d}}$ \\
BRS Querência & $11.75 \pm 0.02^{\mathrm{d}}$ & $1.18 \pm 0.04^{\mathrm{a}, \mathrm{b}}$ & $7.71 \pm 0.18^{\mathrm{d}}$ & $2.08 \pm 0.10^{\mathrm{c}}$ & $77.39 \pm 0.36^{\mathrm{a}}$ \\
BRS Sertaneja & $11.46 \pm 0.05^{\mathrm{e}}$ & $1.12 \pm 0.02^{\mathrm{b}, \mathrm{c}}$ & $11.88 \pm 0.65^{\mathrm{a}}$ & $2.05 \pm 0.15^{\mathrm{c}}$ & $71.97 \pm 2.35^{\mathrm{d}}$ \\
BRS Tropical & $11.96 \pm 0.09^{\mathrm{b}, \mathrm{c}}$ & $1.23 \pm 0.06^{\mathrm{a}, \mathrm{b}}$ & $9.46 \pm 0.48^{\mathrm{b}, \mathrm{c}}$ & $2.63 \pm 0.10^{\mathrm{b}}$ & $74.65 \pm 0.78^{\mathrm{b}, \mathrm{c}}$ \\
BRS Taim & $11.23 \pm 0.05^{\mathrm{f}}$ & $1.28 \pm 0.04^{\mathrm{a}}$ & $11.81 \pm 0.36^{\mathrm{a}}$ & $1.95 \pm 0.01^{\mathrm{c}, \mathrm{d}}$ & $73.52 \pm 0.18^{\mathrm{c}, \mathrm{d}}$ \\
BRS Jaçanã & $12.08 \pm 0.04^{\mathrm{a}, \mathrm{b}}$ & $1.15 \pm 0.02^{\mathrm{b}}$ & $10.51 \pm 0.21^{\mathrm{b}}$ & $1.77 \pm 0.07^{\mathrm{b}}$ & $74.49 \pm 0.15^{\mathrm{b}, \mathrm{c}}$ \\
BRS Pampa & $12.18 \pm 0.09^{\mathrm{a}}$ & $1.18 \pm 0.07^{\mathrm{a}, \mathrm{b}}$ & $8.69 \pm 0.02^{\mathrm{c}, \mathrm{d}}$ & $1.91 \pm 0.13^{\mathrm{c}, \mathrm{d}}$ & $76.05 \pm 0.28^{\mathrm{a}, \mathrm{b}}$ \\
\hline
\end{tabular}

Results expressed as mean \pm standard deviation from the analysis of three replicates. Means followed by different superscript letters ( $\left.{ }^{(}\right)$in the same column are significantly different according to Tukey's test $(\mathrm{p}<0.05)$.

Table 2. Fatty acid quantification (mg g $\mathrm{g}^{-1}$ of total lipid) and n-6/n-3 and PUFA/SFA ratio of the rice cultivars.

\begin{tabular}{|c|c|c|c|c|c|c|c|}
\hline & BRS Primavera & BRS Querência & BRS Sertaneja & BRS Tropical & BRS Taim & BRS Jaçanã & BRS Pampa \\
\hline $14: 0$ & $4.09 \pm 0.28^{\mathrm{a}}$ & $5.31 \pm 2.42^{\mathrm{a}}$ & $3.58 \pm 0.14^{\mathrm{a}}$ & $5.03 \pm 2.54^{\mathrm{a}}$ & $3.30 \pm 0.38^{\mathrm{a}}$ & $3.39 \pm 0.10^{\mathrm{a}}$ & $3.21 \pm 0.01^{\mathrm{a}}$ \\
\hline $16: 0$ & $150.51 \pm 6.18^{c}$ & $217.86 \pm 4.62^{\mathrm{a}}$ & $144.79 \pm 0.40^{c}$ & $191.16 \pm 2.43^{\mathrm{b}}$ & $196.91 \pm 2.75^{b}$ & $225.24 \pm 4.51^{\mathrm{a}}$ & $198.62 \pm 0.95^{\mathrm{b}}$ \\
\hline $18: 0$ & $19.61 \pm 1.50^{\mathrm{a}}$ & $21.73 \pm 2.35^{\mathrm{a}}$ & $24.27 \pm 1.56^{\mathrm{a}}$ & $22.26 \pm 1.16^{\mathrm{a}}$ & $19.26 \pm 0.57^{\mathrm{a}}$ & $22.09 \pm 0.98^{\mathrm{a}}$ & $20.90 \pm 0.20^{\mathrm{a}}$ \\
\hline $18: 1 n-9$ & $421.41 \pm 22.98^{\mathrm{a}, \mathrm{b}, \mathrm{c}}$ & $469.30 \pm 19.70^{\mathrm{a}, \mathrm{b}}$ & $472.10 \pm 26.25^{\mathrm{a}}$ & $405.03 \pm 10.36^{\mathrm{b}, c, \mathrm{~d}}$ & $354.26 \pm 15.64^{\mathrm{d}}$ & $362.42 \pm 1.54^{\mathrm{c}, \mathrm{d}}$ & $358.40 \pm 0.49^{\mathrm{c}, \mathrm{d}}$ \\
\hline $18: 1 n-7$ & $8.03 \pm 0.36^{\mathrm{a}}$ & $7.62 \pm 0.01^{\mathrm{a}, \mathrm{b}}$ & $6.23 \pm 0.75^{\mathrm{b}, \mathrm{c}}$ & $6.03 \pm 0.20^{\mathrm{b}, \mathrm{c}}$ & $6.41 \pm 0.17^{\mathrm{b}, \mathrm{c}}$ & $5.22 \pm 0.15^{c}$ & $5.73 \pm 0.61^{c}$ \\
\hline $18: 2 n-6$ & $406.68 \pm 24.19^{a}$ & $395.04 \pm 21.79^{\mathrm{a}, \mathrm{b}}$ & $341.48 \pm 18.41^{\mathrm{b}, c, \mathrm{~d}}$ & $299.11 \pm 8.21^{\mathrm{d}}$ & $372.30 \pm 14.04^{\mathrm{a}, \mathrm{b}, \mathrm{c}}$ & $402.16 \pm 7.32^{\mathrm{a}, \mathrm{b}}$ & $321.54 \pm 6.72^{\mathrm{c}, \mathrm{d}}$ \\
\hline $18: 3 n-3$ & $12.70 \pm 0.74^{\mathrm{c}}$ & $19.62 \pm 0.79^{\mathrm{a}, \mathrm{b}, \mathrm{c}}$ & $16.92 \pm 5.07^{\mathrm{b}, \mathrm{c}}$ & $15.28 \pm 0.38^{\mathrm{b}, \mathrm{c}}$ & $22.73 \pm 1.53^{\mathrm{a}, \mathrm{b}}$ & $26.73 \pm 0.99^{\mathrm{a}}$ & $17.79 \pm 1.91^{\mathrm{b}, \mathrm{c}}$ \\
\hline $20: 4 n-6$ & $8.19 \pm 0.31^{\mathrm{a}}$ & $7.86 \pm 0.19^{\mathrm{a}}$ & $8.26 \pm 0.23^{\mathrm{a}}$ & $7.18 \pm 0.16^{\mathrm{a}}$ & $5.87 \pm 0.05^{\mathrm{b}}$ & $5.31 \pm 0.69^{\mathrm{b}}$ & $4.80 \pm 0.01^{\mathrm{b}}$ \\
\hline $22: 1 n-9$ & $4.71 \pm 0.25^{\mathrm{b}}$ & $5.56 \pm 0.02^{\mathrm{a}}$ & $4.38 \pm 0.03^{\mathrm{b}, \mathrm{c}}$ & $4.78 \pm 0.09^{\mathrm{b}}$ & $3.98 \pm 0.20^{c}$ & $3.27 \pm 0.18^{\mathrm{d}}$ & $3.36 \pm 0.06^{\mathrm{d}}$ \\
\hline SFA & $174.21 \pm 7.97^{\mathrm{c}}$ & $244.89 \pm 0.15^{\mathrm{a}}$ & $172.63 \pm 1.82^{c}$ & $218.46 \pm 1.27^{b}$ & $219.48 \pm 2.94^{\mathrm{b}}$ & $250.73 \pm 5.60^{\mathrm{a}}$ & $222.73 \pm 1.16^{\mathrm{b}}$ \\
\hline MUFA & $434.15 \pm 23.59^{\mathrm{a}, \mathrm{b}}$ & $482.48 \pm 19.70^{\mathrm{a}}$ & $482.72 \pm 25.48^{\mathrm{a}}$ & $415.84 \pm 10.65^{\mathrm{b}, \mathrm{c}}$ & $364.65 \pm 15.67^{c}$ & $370.91 \pm 1.87^{\mathrm{b}, \mathrm{c}}$ & $367.49 \pm 0.18^{c}$ \\
\hline PUFA & $427.57 \pm 25.24^{\mathrm{a}, \mathrm{b}}$ & $422.52 \pm 22.76^{\mathrm{a}, \mathrm{b}}$ & $366.67 \pm 13.56^{b, c, d}$ & $321.57 \pm 8.75^{\mathrm{d}}$ & $400.89 \pm 15.62^{\mathrm{a}, \mathrm{b}, \mathrm{c}}$ & $434.19 \pm 7.61^{\mathrm{a}}$ & $344.13 \pm 8.64^{c, d}$ \\
\hline$n-6$ & $414.87 \pm 24.50^{\mathrm{a}}$ & $402.90 \pm 21.98^{\mathrm{a}, \mathrm{b}}$ & $349.75 \pm 18.64^{\mathrm{b}, c, d}$ & $306.30 \pm 8.36^{\mathrm{d}}$ & $378.17 \pm 14.09^{\mathrm{a}, \mathrm{b}, \mathrm{c}}$ & $407.47 \pm 6.63^{\mathrm{a}, \mathrm{b}}$ & $326.34 \pm 6.73^{\mathrm{cd} d}$ \\
\hline$n-3$ & $12.70 \pm 0.74^{\mathrm{c}}$ & $19.62 \pm 0.79^{\mathrm{a}, \mathrm{b}, \mathrm{c}}$ & $16.92 \pm 5.07^{\mathrm{b}, \mathrm{c}}$ & $15.28 \pm 0.38^{\mathrm{b}, \mathrm{c}}$ & $22.73 \pm 1.53^{\mathrm{a}, \mathrm{b}}$ & $26.73 \pm 0.99^{\mathrm{a}}$ & $17.79 \pm 1.91^{\mathrm{b}, \mathrm{c}}$ \\
\hline$n-6 / n-3$ & $32.66 \pm 0.02^{\mathrm{a}}$ & $20.53 \pm 0.30^{\mathrm{b}}$ & $21.81 \pm 7.64^{\mathrm{a}, \mathrm{b}}$ & $20.05 \pm 0.04^{\mathrm{b}}$ & $16.66 \pm 0.50^{\mathrm{b}}$ & $15.25 \pm 0.31^{\mathrm{b}}$ & $18.43 \pm 1.61^{\mathrm{b}}$ \\
\hline PUFA/SFA & $2.45 \pm 0.03^{\mathrm{a}}$ & $1.73 \pm 0.09^{c, \mathrm{~d}}$ & $2.12 \pm 0.10^{\mathrm{b}}$ & $1.47 \pm 0.05^{\mathrm{d}}$ & $1.83 \pm 0.05^{\mathrm{c}}$ & $1.73 \pm 0.07^{\mathrm{c}, \mathrm{d}}$ & $1.55 \pm 0.05^{\mathrm{d}}$ \\
\hline
\end{tabular}

Results expressed as mean \pm standard deviation from the analysis of three replicates. Means followed by different superscript letters $\left(^{\mathrm{a}}\right)$ in the same row are significantly different according to Tukey's test $(\mathrm{p}<0.05)$. 
Table 3. Results of antioxidant capacity $\left(\mu \mathrm{mol}\right.$ TEAC $\left.\mathrm{g}^{-1}\right)$ and total phenolic content $\left(\mathrm{mg} \mathrm{GAE} 100 \mathrm{~g}^{-1}\right)$ of the rice cultivars using different assays.

\begin{tabular}{ccccc}
\hline & DPPH & FRAP & ABTS & Total phenolic content \\
\hline BRS Primavera & $794.51 \pm 98.42^{\mathrm{e}}$ & $1073.15 \pm 34.73^{\mathrm{e}}$ & $1562.45 \pm 61.16^{\mathrm{c}, \mathrm{d}}$ & $27.32 \pm 0.76^{\mathrm{d}}$ \\
BRS Querência & $777.13 \pm 50.72^{\mathrm{e}}$ & $1172.85 \pm 34.73^{\mathrm{e}}$ & $1525.78 \pm 27.41^{\mathrm{c}, \mathrm{d}}$ & $30.06 \pm 1.11^{\mathrm{c}}$ \\
BRS Sertaneja & $1145.23 \pm 82.26^{\mathrm{c}}$ & $1417.35 \pm 55.95^{\mathrm{d}}$ & $1518.27 \pm 70.54^{\mathrm{c}, \mathrm{d}}$ & $24.45 \pm 0.82^{\mathrm{e}}$ \\
BRS Tropical & $1201.07 \pm 29.87^{\mathrm{b}, \mathrm{c}}$ & $1612.98 \pm 12.93^{\mathrm{c}}$ & $1819.14 \pm 87.82^{\mathrm{a}, \mathrm{b}}$ & $31.73 \pm 0.30^{\mathrm{c}}$ \\
BRS Taim & $1461.66 \pm 71.96^{\mathrm{a}}$ & $1987.42 \pm 25.09^{\mathrm{a}}$ & $1897.56 \pm 122.93^{\mathrm{a}}$ & $37.93 \pm 1.19^{\mathrm{a}}$ \\
BRS Jaçanã & $1356.67 \pm 41.99^{\mathrm{a}, \mathrm{b}}$ & $1784.79 \pm 47.27^{\mathrm{b}}$ & $1660.71 \pm 44.78^{\mathrm{b}, \mathrm{c}}$ & $34.21 \pm 1.00^{\mathrm{b}}$ \\
BRS Pampa & $970.53 \pm 87.18^{\mathrm{d}}$ & $1339.47 \pm 20.47^{\mathrm{d}}$ & $1464.15 \pm 32.77^{\mathrm{d}}$ & $27.33 \pm 0.48^{\mathrm{d}}$ \\
\hline
\end{tabular}

Results of the analysis of three replicates expressed as mean \pm standard deviation. Means followed by different superscript letters in the same column are significantly different according to Tukey's test ( $p>0.05)$.

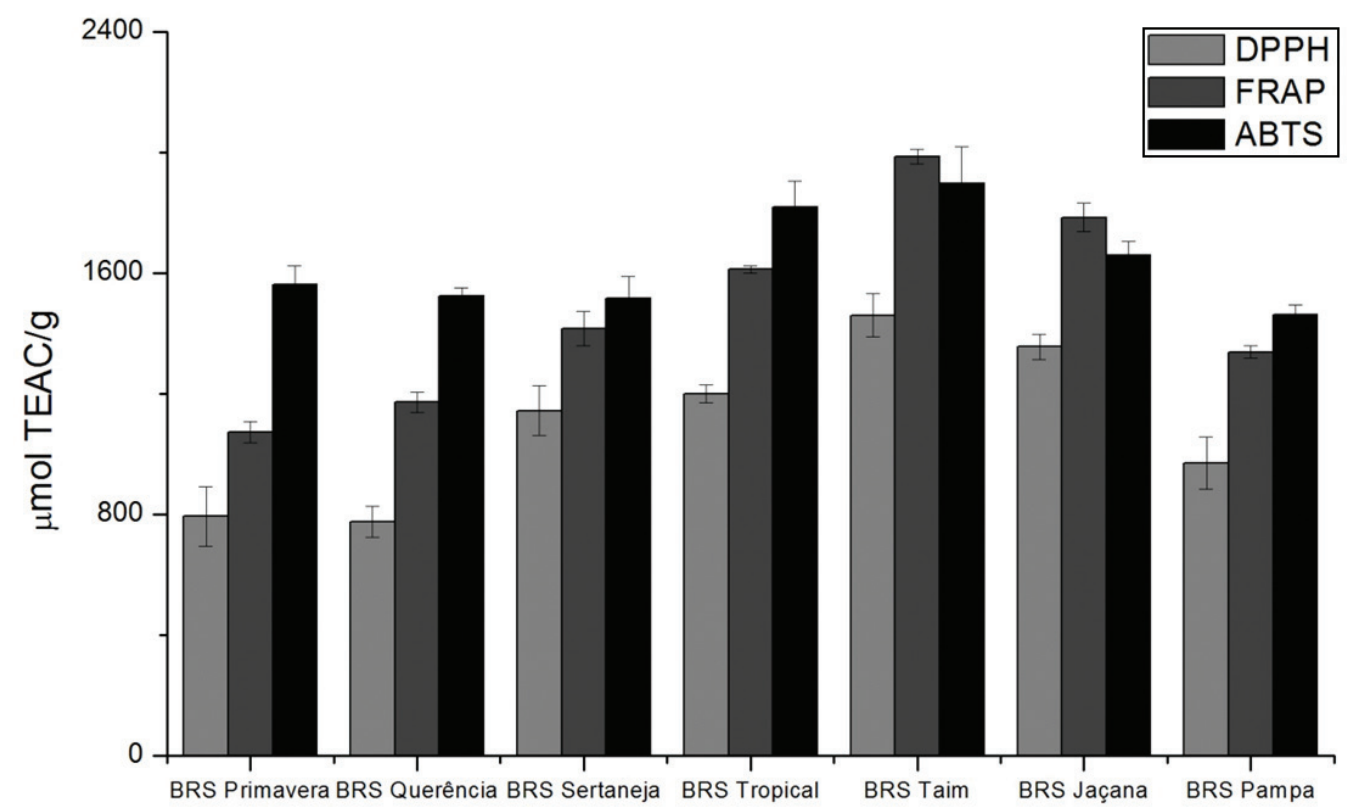

Figure 1. TAA results of Brazilian rice cultivars.

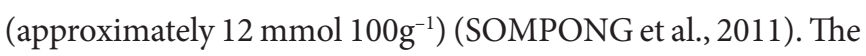
TPC content of the cultivars varied slightly (24.45 to $37.93 \mathrm{mg}$ GAE $100^{-1}$ ); these values were within the range determined by

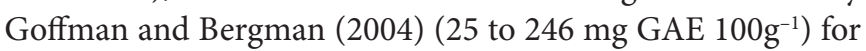
white rice and indicate that the cultivars analyzed in this study had good antioxidant activity compared to that of other rice cultivars from around the world.

The correlation values obtained (Table 4) may explain the TAA value in the rice cultivars. A high correlation was observed between the FRAP and DPPH assays, suggesting a possible antioxidant activity relationship of the compounds that react in both methods although they that have different reaction mechanisms. The same did not occur in FRAP $\times$ ABTS and $\mathrm{DPPH} \times \mathrm{ABTS}$ correlations even though the FRAP and ABTS assays showed similarities with regard to the redox potential $(0.70 \mathrm{~V}$ for ferric reduction and $0.68 \mathrm{~V}$ for reaction with ABTS). It can be said that there are some differences between the methods studied. Unlike the ABTS procedure, the FRAP assay, for example, is conducted at controlled $\mathrm{pH}$ (3.6), changing the conditions of the reaction in the samples. Moreover, there are different steric effects between the oxidant molecules and
Table 4. Correlation coefficients (R) between the analyses' results.

\begin{tabular}{lccc}
\hline & DPPH & FRAP & ABTS \\
\hline Total phenolic content & 0.462 & 0.646 & 0.693 \\
DPPH & - & 0.957 & 0.538 \\
FRAP & - & - & 0.634 \\
\hline
\end{tabular}

the Fe ${ }^{\mathrm{III}}-\mathrm{TPTZ}_{2}$ complex (in FRAP) and the $\mathrm{ABTS}^{\bullet+}$ radical (MÜLLER; FRÖHLICH; BÖHM, 2011).

A greater correlation between the results from the $\mathrm{DPPH}$ and ABTS assays was expected due to the fact that both methods share the same reaction mechanism, electron transfer (HUANG; OU; PRIOR, 2005). However, there are some important differences among these methods. The solvent used for solubilization of the DPPH and ABTS radicals in the Quencher procedure was a mixture of ethanol and water (50:50, $\mathrm{v} / \mathrm{v})$, based on the yield results reported by Serpen, Gökmen and Fogliano (2012b), who found the best results with the direct procedure using this mixture. The DPPH radical, for example, is more suitable for application in hydrophobic systems since it is better solubilized in solvents with low polarity. On the other 
hand, the ABTS radical can be used in both hydrophilic and lipophilic systems (SERPEN; GÖKMEN; FOGLIANO, 2012b; KIM et al., 2002). This difference of action between the DPPH and ABTS radicals can also explain the trend identified in the TAA results (Figure 1), in which higher values were obtained for the cultivars in the ABTS assay compared to those of the DPPH assay. Since the radical acts directly in the food matrix during the quenching process, the ABTS radical can react with a greater amount of compounds than the DPPH because it is applicable to both hydrophilic and lipophilic systems, which are present in the reactional media.

The correlation between the TPC and TAA results was not as high as expected, and greater values were observed in the FRAP and ABTS assays. There are some factors that may help explain this situation. The first one is the difference in the steps applied in each method. In the TAA assays, the direct procedure (Quencher) was applied, and it did not use analyte extraction steps or solvents. This procedure is widely recognized because it covers a greater range of compounds by reacting directly in the food matrix and reaching extensive range of compound polarities that are present in the samples (GÖKMEN; SERPEN; FOGLIANO, 2009). The same was not observed in the TPC assay, which included an extraction step with a mixture of ethanol and water $(50: 50, \mathrm{v} / \mathrm{v})$, thus reducing the range of detectable compounds. This idea is reinforced by Pérez-Jiménez and Saura-Calixto (2005), who claimed that the antioxidant capacity of the non-extractable polyphenol portion in cereals greatly exceeded the TAA of the usual extracts. As already known, the method used in this study only detects the extractable portion of phenolic compounds. Even with this evident procedural difference, the correlation between the TPC and ABTS data was greater than that reported by Shen et al. (2009) $(r=0.231)$ for white rice. This shows that the correlation value can be affected depending on whether or not the Quencher procedure should be used; however, this issue is not problematic enough to avoid its use in determining TAA.

Another factor that might have influenced the relative low correlation observed between the TPC and TAA results can be, according to Rocha-Guzmán et al. (2007), the presence of carbohydrates in the reactional media. On a study on bean samples, which is as rich in carbohydrates as rice, these authors found a poor correlation between TAA and TPC $(r=0.0694)$. They explained that the carbohydrates in the media take up an electron but cannot form a stable free radical, and thus the electron that was taken returns to the reactional media soon after. This is a plausible explanation in for the results obtained in the present study since the solvent that was used to solubilize the radicals in the Quencher procedure was a mixture of ethanol and water (50:50, v/v), which also solubilizes carbohydrates.

Finally, the synergistic effects of the antioxidants must be taken into account to corroborate the explanations about the correlations found (TANANUWONG; TEWARUTH, 2010). These effects between the antioxidants present in the food matrix, which can be detected with the Quencher procedure, may also have lower the correlation since they were not observed in the TPC assays because it only one solvent was used for the analyte extraction thus limiting the synergism of the compounds.

\section{Conclusions}

The rice cultivars analyzed in this study can be considered healthy due to their PUFA/SFA ratios and to the fact that they have higher concentrations of oleic and $\alpha$-linolenic fatty acids compared to that of other rice samples reported in the literature. Their antioxidant capacities were also much higher than those reported for other varieties worldwide. Thus, the Quencher procedure is highly suitable for application in cereals such as rice, especially when combined with the ABTS radical capture method, which showed the best results.

\section{Acknowledgments}

The authors are grateful for the financial support provided by Capes and to the Brazilian Agricultural Research Corporation, Unit Arroz e Feijão, Santo Antônio de Goiás, Goiás, Brazil, for donating the grains.

\section{References}

AÇAR, Ö. Ç.; GÖKMEN, V.; PELLEGRINI, N. Direct evaluation of the total antioxidant capacity of raw and roasted pulses, nuts and seeds. European Food Research and Technology, v. 229, p. 961-969, 2009. http://dx.doi.org/10.1007/s00217-009-1131-z

ASSOCIATION OF OFFICIAL ANALYTICAL CHEMISTS - AOAC. Official Methods of Analysis. 15th ed. Arlington: AOAC, 1990.

BENZIE, I. F. F.; STRAIN, J. J. The Ferric Reducing Ability of Plasma (FRAP) as a Measure of "Antioxidant Power": The FRAP Assay. Analytical Biochemistry, v. 239, p. 70-76, 1996. PMid:8660627. http://dx.doi.org/10.1006/abio.1996.0292

BLIGH, E. G.; DYER, W. J. A rapid method of total lipid extraction and purification. Canadian Journal of Biochemistry and Physiology, v. 37, p. 911-917, 1959. PMid:13671378. http://dx.doi.org/10.1139/ o59-099

BRAND-WILLIAMS, W.; CUVELIER, M. E.; BERSET, C. Use of a free radical method to evaluate antioxidant activity. LWT- Food Science and Technology, v. 28, p. 25-30, 1995.

CAO, C.; ALESSIO, H. M.; CUTLER, R. G. Oxygen-radical absorbance capacity assay for antioxidants. Free Radical Biology \& Medicine, v. 14, p. 303-311, 1993. http://dx.doi.org/10.1016/08915849(93)90027-R

ELMADFA, I.; KORNSTEINER, M. Fats and fatty acid requirements for adults. Annals of Nutrition and Metabolism, v. 55, p. 56-75, 2009. PMid:19752536. http://dx.doi.org/10.1159/000228996

FOOD AND AGRICULTURE ORGANIZATION OF THE UNITED NATIONS. FAOSTAT. 2013. Disponível em: <http://faostat.fao. org/site/339/default.aspx>. Acesso em 25 mar. 2013.

GOFFMAN, F. D.; BERGMAN, C. J. Rice kernel phenolic content and its relationship with antiradical efficiency. Journal of the Science of Food and Agriculture, v. 84, p. 1235-1240, 2004. http://dx.doi. org/10.1002/jsfa. 1780

GÖKMEN, V.; SERPEN, A.; FOGLIANO, V. Direct measurement of the total antioxidant capacity of foods: the 'QUENCHER' approach. Trends LWT- Food Science and Technology, v. 20, p. 278-288, 2009. 
HARTMAN, L.; LAGO, R. C. A. Rapid preparation of fatty acid methyl esters from lipids. Laboratory Practice, v. 22, p. 475-476, 1973. PMid:4727126.

HUANG, D.; OU, B.; PRIOR, R. L. The Chemistry Behind Antioxidant Capacity Assays. Journal of Agricultural and Food Chemistry, v. 53, p. 1841-1856, 2005. PMid:15769103. http://dx.doi. org/10.1021/jf030723c

JOSEPH, J. D.; ACKMAN, R. G. Cappilary column gas chromatography method for analysis of encapsulated fish and oil ethyl esters: collaborative study. Journal of AOAC International, v. 75, p. 488506, 1992.

JULIANO, B. O. Rice. In: WRIGLEY, C.; CORKE, H.; WALKER, C. E. (Ed.). Encyclopedia of Grain Science. North Ryde: Academic Press; 2004. p. 41-85. http://dx.doi.org/10.1016/B0-12-765490-9/00209-3

KIM, D. O. et al. Vitamins C Equivalent Antioxidant Capacity (VCEAC) of Phenolic Phytochemicals. Journal of Agricultural and Food Chemistry, v. 50, p. 3713-3717, 2002. PMid:12059148. http://dx.doi. org/10.1021/jf020071c

KITTA, K. et al. Variations in lipid content and fatty acid composition of major non-glutinous rice cultivars in Japan. Journal of Food Composition and Analysis, v. 18, p. 269-278, 2005. http://dx.doi. org/10.1016/j.jfca.2004.10.001

KLAUNIG, J. E. et al. Oxidative stress and oxidative damage in chemical carcinogenesis. Toxicology and Applied Pharmacology, v. 254, p. 86-99, 2011. PMid:21296097. http://dx.doi.org/10.1016/j. taap.2009.11.028

LEVINE, M. et al. Vitamin C pharmacokinetics in healthy volunteers: evidence for a recommended dietary allowance. Proceedings of the National Academy of Sciences of the USA, v. 93, p. 3704-3709, 1996. PMid:8623000 PMCid:PMC39676. http://dx.doi.org/10.1073/ pnas.93.8.3704

LONDON. Department of Health. Nutritional aspects of cardiovascular disease. Report of the cardiovascular review group of the committee on medical aspects of food policy. London: HMSO, 1994. In Report on health and social objects.

MONKS, J. L. F. et al. Effects of milling on proximate composition, folic acid, fatty acids and technological properties of rice. Journal of Food Composition and Analysis, v. 30, n. 2, p. 73-79, 2013. http://dx.doi.org/10.1016/j.jfca.2013.01.009

MÜLLER, L.; FRÖHLICH, K.; BÖHM, V. Comparative antioxidant activities of carotenoids measured by ferric reducing antioxidant power (FRAP), ABTS bleaching assay ( $\mathrm{ATEAC)}$, DPPH assay and peroxyl radical scavenging assay. Food Chemistryistry, v. 129, p. 139-148, 2011. http://dx.doi.org/10.1016/j.foodchem.2011.04.045

ODUGUWA, O. O.; EDEMA, M. O.; AYENI, A. O. Physico-chemical and microbiological analyses of fermented corn cob, rice bran and cowpea husk for use in composite rabbit feed. Bioresource Technology, v. 99, p. 1816-1820, 2008. PMid:17502134. http:// dx.doi.org/10.1016/j.biortech.2007.03.036

PADOVANI, R. M. et al. Comparison of proximate, mineral and vitamin composition of common Brazilian and US foods. Journal of Food Composition and Analysis, v. 20, p. 733-738, 2007. http:// dx.doi.org/10.1016/j.jfca.2007.03.006

PÉREZ-JIMÉNEZ, J.; SAURA-CALIXTO, F. Literature Data May Underestimate the Actual Antioxidant Capacity of Cereals. Journal of Agricultural and Food Chemistry, v. 53, p. 5036-5040, 2005. PMid:15941353. http://dx.doi.org/10.1021/jf050049u
PERINI, J. A. L. et al. Omega-3 and omega- 6 polyunsaturated fatty acids: metabolism in mammals and immune response. Brazilian Journal of Nutrition, v. 23, p. 1075-1086, 2010.

QIU, Y.; LIU, Q.; BETA, T. Antioxidant properties of commercial wild rice and analysis of soluble and insoluble phenolic acids. Food Chemistryistry, v. 121, p. 140-147, 2010. http://dx.doi. org/10.1016/j.foodchem.2009.12.021

RE, R. et al. Antioxidant activity applying an improved ABTS radical cation decolorization assay. Free Radical Biology \& Medicine, v. 26, p. 1231-1237, 1999. http://dx.doi.org/10.1016/S08915849(98)00315-3

ROCHA-GUZMÁN, N. E. et al. Antioxidant and antimutagenic activity of phenolic compounds in three different colour groups of common bean cultivars (Phaseolus vulgaris). Food Chemistry, v. 103, p. 521527, 2007. http://dx.doi.org/10.1016/j.foodchem.2006.08.021

SANTOS, L. P. et al. Phenolic compounds and fatty acids in different parts of Vitis labrusca and V. vinifera grapes. Food Research International, v. 44, p. 1414-1418, 2011. http://dx.doi.org/10.1016/j. foodres.2011.02.022

SELLAPAN, K. et al. Rice caryopsis structure in relation to distribution of micronutrients (iron, zinc, $\beta$-carotene) of rice cultivars including transgenic indica rice. Plant Science, v. 177, p. 557-562, 2009. http:// dx.doi.org/10.1016/j.plantsci.2009.07.004

SERPEN, A. et al. Direct measurement of the total antioxidant capacity of cereal products. Journal of Cereal Science, v. 48, p. 816-820, 2008. http://dx.doi.org/10.1016/j.jcs.2008.06.002

SERPEN, A.; GÖKMEN, V.; FOGLIANO, V. Total antioxidant capacities of raw and cooked meats. Meat Science, v. 90, p. 60-65, 2012a. PMid:21684086. http://dx.doi.org/10.1016/j.meatsci.2011.05.027

SERPEN, A.; GÖKMEN, V.; FOGLIANO, V. Solvent effects on total antioxidant capacity of foods measured by direct QUENCHER procedure. Journal of Food Composition and Analysis, v. 26, p. 52-57, 2012b. http://dx.doi.org/10.1016/j.jfca.2012.02.005

SHAHIDI, F.; NACZK, M. Methods of analysis and quantification of phenolic compounds. In: SHAHIDI, F.; NACZK, M. Food phenolics: Sources, chemistry, effects and applications. Lancaster: Technomic Publishing Company, 1995. p. 287-293.

SHEN, Y. et al. Total phenolics, flavonoids, antioxidant capacity in rice grain and their relations to grain color, size and weight. Journal of Cereal Science, v. 49, p. 106-111, 2009. http://dx.doi.org/10.1016/j. jcs.2008.07.010

SIES, H.; STAHL, W. Vitamins E and C, $\beta$-carotene, and other carotenoids as antioxidants. American Journal of Clinical Nutrition, v. 62, p. 1315-1321, 1995.

SOMPONG, R. et al. Physicochemical and antioxidative properties of red and black rice varieties from Thailand, China and Sri Lanka. Food Chemistryistry, v. 124, p. 132-140, 2011. http://dx.doi. org/10.1016/j.foodchem.2010.05.115

TANANUWONG, K.; TEWARUTH, W. Extraction and application of antioxidants from black glutinous rice. LWT- Food Science and Technology, v. 43, p. 476-481, 2010.

ZIGONEANU, I. G. et al. Determination of antioxidant components in rice bran oil extracted by microwave-assisted method. Bioresource Technology, v. 99, p. 4910-4918, 2008. PMid:17996444. http:// dx.doi.org/10.1016/j.biortech.2007.09.067 